\title{
Global Constitutionalism as a Method in International Economic Law
}

\section{Andreas. R. Ziegler \& Xinyan Zhao*}

Abstract:

Constitutionalism was traditionally a domestic law doctrine contending the institutionalization of power, the protection of fundamental (human) rights of individuals as citizens, and the rule of law. Given its value in promoting good governance in democratic societies, constitutionalism has been broadly discussed by international law scholars as a means to promote good global governance. Originally this was limited to human rights, but later extended to other shared values like the fight against nationalism and protectionism. This chapter focuses on the impact of constitutionalism on international economic law (IEL). We consider the role constitutionalism played in the development of international economic law, as well as current criticisms concerning its application in this area. Scholars have tried to link the legal and philosophical ideas of constitutionalism with economic theories, in particular ordo-liberalism which has led to particularly harsh criticism (as it is common in economic theory when it comes to the role of markets and price mechanisms as well as the role of enforceable individual rights [of capital owners and entrepreneurs]). We argue that despite this highly political controversy, constitutionalism had considerably contributed to the development and judicialization of international economic law and will continue to exert an effect on this matter.

Keywords: global constitutionalism, constitutionalization, international economic law, liberalism, good governance, methodology

\footnotetext{
* Andreas R. Ziegler, Full Professor and Chair in Public International Law as well as Director of the LLM Programme in International Business Law, University of Lausanne. Xinyan Zhao, Ph.D. Candidate, University of Lausanne.
} 


\section{Introduction}

Constitutionalism is a concept that different writers use differently. ${ }^{1}$ This is, mostly due to its parallel origin in different national legal systems and the historic context within which it emerged (enlightenment, industrial revolution, globalization). Generally, one can say that the concept originated from the ideas leading to the Declaration of Independence of the United States (1776) (based on theories developed especially in the United Kingdom and France) ${ }^{2}$ and the French Revolution (1789) towards the end of the eighteenth century. After these two remarkable historical movements, a series of constitutional norms were deeply anchored in the hearts and souls of millions of people in Europe and the Americas ${ }^{3}$ though these ideas have always met with a lot of opposition and continue to do so. The Declaration of the Rights of Man and Citizens of 1789 claims liberty, equality, natural (human) rights, the rule of law, the limitation of power, the institutionalization of power, and the separation of powers. ${ }^{4}$ These elements to wit, limitation of power, the institutionalization of decision-making and control, social idealism, the standard-setting capacity of constitutions in the sense of a systematization of law, and the recognition of individual rights and/or freedoms, can be seen as core elements of any type of constitutionalism. ${ }^{5}$

Thomas Paine, in his Rights of Man, in 1792 reiterated his belief of John Locke's social contract theory:

'[I]ndividuals themselves, each in his own personal and sovereign right, entered into a compact with each other to produce a government: and this is

\footnotetext{
${ }^{1}$ For a recent overview see Richard Albert (ed.), Revolutionary Constitutionalism - Law, Legitimacy, Power (Hart 2020).

2 One can try to trace back these concepts to English antecedents going back to Magna Carta (1215), as it is for example done by Bernard Schwartz, The Roots of the Bill of Rights (5 vols., Chelsea House Publisher 1980).

${ }^{3}$ One should not forget the influence in the Caribbean, Central America and South America.

${ }^{4}$ See Declaration of the Rights of Man and Citizens 1789.

5 Christine Schwöbel-Patel, 'Global Constitutionalism and East Asian Perspectives in the Context of Political Economy’ in Thomas Kleinlein and Anne Peters (eds), International Constitutional Law (OUP 2014), 104.
} 
the only mode in which governments have a right to arise, and the only principle on which they have a right to exist'. ${ }^{6}$

In the views of social contract philosophers, one must interpret a constitution as a contractual relationship between a State and its citizens, upon which citizens fulfil their equality and natural rights due to their status as constituent members. ${ }^{7}$ It is thus based on the idea of the social contract as developed in the Era of Enlightenment and several basic elements that can be combined in different ways. ${ }^{8}$ The term "constitutionalism" is very much due to the idea what the ideal constitution (of a State) should look like in particular by limiting the absolute power of the monarch or government. In view of the importance of the respect of these principles enshrined in the constitution, it entails normally a request for a strict supremacy of these constitutional principles over any other regulations. This leads automatically to the question of the role of courts or independent bodies controlling this hierarchy. The latter elements are particularly present in the French Declaration of Human Rights (Déclaration des droits de l'homme et du citoyen) in 1789. Famous contributors to this debate were Abbé Sieyès regarding constitutional control ${ }^{9}$ or Montesquieu regarding the separation of powers 10 (published in Geneva) and Jean-Jacques Rousseau (born in Geneva) regarding the social contract ${ }^{11}$.

While some authors interested in international relations and, more particularly, international law as such, had used the concept of constitutionalism early on (for

\footnotetext{
6 Thomas Paine, Rights of Man (J. Johnson 1791) 2.

7 Ibid., 1 and 8. See also more recently for an overview on this time Simone Zurbuchen, The Law of Nations and Natural Law (Brill 2019) 1625-800.

${ }^{8}$ See, for example Mark Hulliung, Enlightenment in Scotland and France (Routledge 2019) or Takashi Inoguchi, and Quynh Le Lien Thi (eds), The Development of Global Legislative Politics (Springer 2020).

9 See, for example, Marco Fioravanti, 'Sieyès et le jury constitutionnaire: Perspectives historico-juridiques' (2007) 349 Annales historiques de la Révolution française 87.

${ }^{10}$ Charles-Louis de Secondat, Baron de La Brède et de Montesquieu, De l'esprit des loix (first published 1748, Flammarion 2013).

11 Jean-Jacques Rousseau, Du contrat social ou Principes du droit politique (first published 1762, J'ai Lu 2013).
} 
example, Grotius ${ }^{12}$, Pufendorf ${ }^{13}$, and $\mathrm{Kant}^{14}$ ) it came to prominence as a method of approaching international relations (and thus international law) in the $20^{\text {th }}$ century. ${ }^{15}$ In particular, the end of the Second World War and the end of the Cold War provided opportunities for the spread of constitutional theory worldwide, most importantly in regions particularly affected by the political changes like Germany. Here we often find the terms "international", "global" or "cosmopolitan constitutionalism"- in order to describe this extension of the national concept to an international (and maybe even supranational) level.

Verdross, as a member of the Kelsenian school, developed a theory of international constitutionalism based on the UN Charter and jus cogens norms thereof. ${ }^{16}$ On 26 June 1945, by signing the UN Charter, contracting parties agreed to be subject to a constellation of higher norms than those of domestic law, namely jus cogens norms that, according to Verdross, include States' sovereignty, individual's human rights, and all norms embedded in the UN Charter. ${ }^{17}$ This Verdrossian international constitutional theory provided a theoretical underpinning of how international relations (and institutions) should be based on the idea of social contract ensuring the enforcement of jus cogens norms (including domestic constitutional norms) in international law. ${ }^{18}$

\footnotetext{
12 See, for example, Peter Borschberg, Grotius, the Social Contract and Political Resistance. A Study of the Unpublished Theses LVI (Institute for International Law and Justice New York University School of Law, Working Paper, History and Theory of International Law Series, 2006) or Désiré Frans Scheltens, 'Grotius' Doctrine of the Social Contract' (1983) 30(1) Netherlands International Law Review 43.

13 See Luiz Andrade and Silva Sahd, 'The Samuel Pufendorf's Social Contract' (2009) 21(28) Revista de Filosofia: Aurora 143.

${ }^{14}$ See Elizabeth Ellis (ed.), Kant's Political Theory: Interpretations and Applications (Penn State University Press 2012).

15 See for a good overview: Nikolaos K. Tsagourias (ed.), Transnational constitutionalism (CUP 2007) or Christine Schwöbel-Patel, Global constitutionalism in international legal perspective (Nijhoff 2011).

16 Thomas Kleinlein, 'Alfred Verdross as a Founding Father of International Constitutionalism?' (2012) 2 Goettingen Journal of International Law 385; See also Aoife O'Donoghue, 'Alfred Verdross and the Contemporary Constitutionalization Debate' (2012) 32 (4) Oxford Journal of Legal Studies 799, 813.

17 Alfred Verdross, 'Reichsrecht und Internationales Recht. Eine Lanze für Art 3 des Regierungsentwurfs der Deutschen Verfassung' (1919) 24 Deutsche Juristenzeitung 291; Alfred Verdross, 'On the Concept of International Law' (1949) 43 AJIL 435; Alfred Verdross, 'Jus Dispositivum and Jus Cogens in International Law' (1966) 60 AJIL 55; Aoife O’Donoghue, supra note 16, 808.

18 Thomas Weatherall, Jus Cogens: International Law and Social Contract (CUP 2015), 17; See for a recent overview Takao Suami et al. (eds), Global Constitutionalism from European and East Asian Perspectives (CUP 2018) and Aydin Atilgan, Global Constitutionalism: A Socio-legal Perspective (Springer 2018).
} 
Following the Verdrossian theory, many German-speaking scholars (and their pupils), including Hermann Mosler ${ }^{19}$, Christian Tomuschat ${ }^{20}$, Bruno Simma ${ }^{21}$, as well as more recently Anne Peters, Bardo Fassbender ${ }^{22}$, Armin von Bogdandy and Nico Krisch (but also other scholars influenced by their writings such as Erika de Wet, Jan Klabbers or

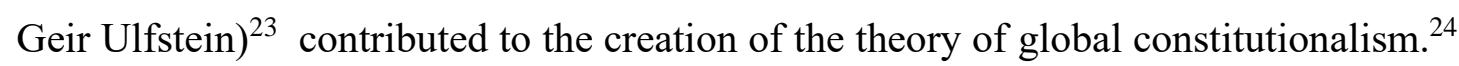
Their theories that build on the UN Charter of 1945 established a norms-based international (constitutional) order in opposition to that depicted by Hegel. ${ }^{25}$ For them and influenced by the German experience in the 1930s, the protection of human rights (and in particular democracy) through certain principles should be safeguarded by international institutions (including courts). In this respect, they often use the term “international community" as well as insights from the (then) European Community and the role of the European Court of Justice and the European Court of Human Rights.

To date, through these aforementioned stages of development, the institutional claims (rule of law, transparency, judicial control, human rights etc.) made in the context of the American and French revolutions have not only been included in the majority of State constitutions, ${ }^{26}$ but are also regarded as part of international law, to various degree. The concept of international or "global governance" is often used to describe this. It refers to the increasingly organized and internationalized attempt to save the lives, enhance the welfare, and reduce the suffering of the world's most vulnerable

\footnotetext{
${ }^{19}$ Mostly towards the end of his life but thereby influencing many young scholars as Director of the Max Planck Institute for Comparative Public Law and International Law in Heidelberg, e.g. Hermann Mosler, The international society as a legal community (Springer 1980).

20 See, for example, Christian Tomuschat, 'Die internationale Gemeinschaft' (1995) 33(1-2) Archiv des Völkerrechts S. 1-20.

${ }^{21}$ See, for example, Bruno Simma, 'The "international community": facing the challenge of globalization' (1998)

9(2) European journal of international law S. 266-77.

22 See Aoife O'Donoghue, supra note 16, 814-21.

${ }^{23}$ See Jan Klabbers, Anne Peters and Geir Ulfstein, The Constitutionalization of International Law (OUP 2009). Some later also questioned these developments: by Andreas Follesdal and Geir Ulfstein (eds), The Judicialization of International Law - A Mixed Blessing? (OUP 2018).

${ }^{24}$ Some go so far to claim the constitutional approach to international law is a German concept: Rainer Wahl, 'In Defence of Constitution' in Petra Dobener and Martin Loughlin (eds), The Twilight of Constitutionalism? (OUP 2010), 225.

${ }^{25}$ Bardo Fassbender, 'The United Nations Charter as Constitution of the International Community' (1998) 36(3) Columbia Journal of Transnational Law 529; See also Aoife O’Donoghue, supra note 16, 804.

${ }^{26}$ See The Economist Intelligence Unit, the Democracy Index 2018, 4. According to this report, 75 of 167 countries, accounting for $44.9 \%$ countries and $47.7 \%$ population of the world, are democracies, while only 53 of 167 countries, accounting for $31.7 \%$ countries and $35.6 \%$ population of the world, are of authoritarian regimes.
} 
populations. ${ }^{27}$ It can be viewed as the modern (more complicated) version of the "eternal or perpetual peace" (including the economic well-being of human beings and the sustainable development of this planet) desired by so many thinkers over time. ${ }^{28}$

Nonetheless, although the United Nations confirmed its ambition to promote good global governance implementing these constitutional norms ${ }^{29}$, the realization of these values and norms (as international law in general) has often suffered from less enthusiasm and support. As a result, concepts like multi-layered governance or subsidiarity ${ }^{30}$ have often been added to the debate to make the use of constitutional ideas at different levels acceptable and to find an instrument to justify their existence. This would allow constitutional principles to be respected at all levels and, in particular, leave some discretion at lower levels, in particular where more rights and guarantees are protected. This should help to counter the claim that centralisation and globalisation reduce the rule of law and the protection of democracy and the public interest at the lower level. ${ }^{31}$

\section{The Use of Constitutionalism as a Method in IEL}

Global constitutionalism, although it is realised by the international community on a limited scale, had a considerable impact on the development of international economic law (IEL). Since the 1990s, along with the increase of international trade and

27 See e.g., Michael N. Barnett, 'Humanitarian Governance' (2013) 16 The Annual Review of Political Science 379.

${ }^{28}$ Immanuel Kant's attempt at it (Immanuel Kant, Perpetual Peace: A Philosophical Sketch (F. Nicolovius 1795)) may be the most well-known.

29 The UN Charter, Article 1, para.3. See Graham Burchell, Colin Gordon, and Peter Miller, The Foucault Effect: Studies in Governmentality (The University of Chicago Press 1991), 87-104. Foucault defined humanitarian governance as an alternative to the conventional global governance: it is understood as the project to 'secure the welfare of the population, the improvement of its condition, the increase of its wealth, longevity, health', and the betterment of its general well-being; See Didier Fassin, 'Humanitarianism: A Nongovernmental Government' in Michel Feher (ed.), Nongovernmental Politics (Zone Books 2007). Humanitarian governance is referred to as the administration of human collectivities in the name of a higher moral principle that sees the preservation of life and the alleviation of suffering as the highest value of action. See also Michael N. Barnett, supra note 27, 379-98.

${ }^{30}$ See for example, Andreas Follesdal, 'The principle of subsidiarity as a constitutional principle in international law, Global Constitutionalism' (2013) 2(1) Global Constitutionalism 37.

${ }^{31}$ See the debate on the introduction of the subsidiarity principle in Article 5.3 of the Maastricht Treaty of the European Union in 1992. See, for example, Fremuth and Michael Lysander, 'Patchwork constitutionalism' (2011) 49(2) Duquesne law review 339. 
investment flows, IEL scholars needed to find an appropriate methodology for improving the regulation/judicialization of international trade and investment. Some of them started to refer to the concept of international constitutionalism and imported these constitutional norms into the realm of IEL. However, the use of constitutionalism in IEL remains controversial.

\subsection{Institutions and Dispute Settlement}

At the first stage, IEL scholars started to consider constitutionalism (or constitutionalsation) as a method for institutionalizing international economic law and fighting protectionism, rent-seeking, nationalism and arbitrariness. Here John Jackson ${ }^{32}$ (1932-2015), as described above (much more than his contemporaries Robert Hudec ${ }^{33}$ (1935-2003) and Kenneth Dam $^{34}$ (1932- ) was at the forefront with regard to trade. The most important opportunity to do so was the establishment of the WTO, which was inspired by John Jackson's thoughts of global constitutionalism. ${ }^{35}$ Jackson's theory originated in his concern about 'human institutions' and 'sovereignty' (inspired by the ideas of the US Constitutions and its fathers). He stated that:

'We do not trust humans enough to be very comfortable with a monopoly of power in any human institution, so we want to prevent a monopoly of power. This leads to a struggle among power centers that can arguably promote good and long-lasting approaches to constitutionalism'.... And what is happeningboth with respect to the new subjects and indeed to the GATT itself- with more focus on the national treatment clause of Article 3, is that its procedures and its norms are beginning to touch the vital nerves of the ' $S$ ' word:

\footnotetext{
32 See John Howard Jackson, World trade and the law of GATT (Bobbs-Merrill 1969).

33 See Robert F. Hudec, The GATT legal system and world trade diplomacy (Praeger 1975).

34 See Kenneth W. Dam, The GATT: Law and International Economic Organization (Univ. of Chicago Press 1970).

35 On Jackson's role from a US perspective see Joel Trachtman, 'John Jackson and the Founding of the World Trade Organisation'(1999) 20(2) Michigan Journal of International Law 175 and more critically David Kennedy, 'The International Style in Postwar Law and Policy: John Jackson and the Field of International Economic Law'(1995) 10(2) American University Journal of International Law and Policy 671.
} 
sovereignty. In other words, the vital nerves of how national governments go about their economic regulation are being brought into play in connection with these matters of competence in the WTO. Thus, these matters have caused a great deal more public interest'.$^{36}$

In view of those concerns, Jackson advocated establishing a constitutional structure for the WTO. He believed that the constitutional structure is in favour of a rules-based WTO decision-making process, and that it fits in a more globalized and interdependent economy. ${ }^{37}$ In the view of Jackson, the WTO's constitutional structure gives a sense of constitutionalism. ${ }^{38}$ And its legitimacy, according to him, comes from the following points $^{39}$ :

(1) The goal in economic affairs has been to limit governments, creating a rule structure that provides a certain amount of predictability and stability, which will help shape how those millions and millions of economic decisions are and can be made;

(2) the predictability based on this constitutional structure will allow entrepreneurs to reduce what is often called the 'risk premium';

(3) the development history of the GATT/WTO institution, notably Article 16 of the WTO Agreement, has proved its constitutional evolution;

(4) the need for the separation of powers;

(5) the constitutional and jurisprudential development within the WTO;

(6) the procedure of WTO adjudication;

(7) the need for compliance.

Jackson argued that the institutionalization of the WTO can ensure a gradual evolution of the WTO from a power-oriented approach, in the state of nature, towards a rule-

\footnotetext{
36 John H. Jackson, 'Fragmentation or Unification Among International Institutions: The World Trade Organization' (1999) 31(4) International Law and Politics 823, 824-5.

37 Ibid., 824 .

38 John H. Jackson, 'The Perils of Globalization and the World Trading System' (2000) 24(1-2) Fordham Int'I L. J. $371,375$.

39 John H. Jackson, supra note $36,825-30$.
} 
oriented approach that provides the security and predictability necessary for decentralized international markets to function. ${ }^{40}$ It comes as no surprise that many of the European authors who were later going to use constitutionalism as a method to develop IEL were studying with John Jackson or working closely with him. Here one can mention in particular Ernst-Ulrich Petersmann, Meinhard Hilf and Thomas Cottier (whose work will be discussed below). ${ }^{41}$ While Jackson focused his research on the existence of global institutions that defend a rule-based trading system (including through the use of dispute settlement), the European (and particularly German) scholars added the important debate on individual (economic) rights to defend this order (in particular against governments by being given the chance to enforce their rights before national (and possible international courts).

The impact of Jackson's constitutional theory on IEL is remarkable. As Debra P. Steger notes, Jackson was the WTO institution builder who firstly coined the idea of creating the WTO and then personally prepared the draft agreement for the negotiation on its establishment. ${ }^{42}$ Most importantly, nearly all of his ideas were written in the Marrakesh Agreement Establishing the World Trade Organization. Although the WTO institution was still needed to be improved ${ }^{43}$ because Jackson's constitutional thoughts were not completely accepted by WTO negotiators in the final version of the Marrakesh Agreement, its value had even been recognized by scholars who often remain suspicious of international law. As an example, Zhipeng He appraised the WTO that: 'Although power still occupies a very important position in today's international relations, it does not mean that international law is completely subordinated to power...The United States, the European Union, and China are often sued in the WTO

\footnotetext{
40 John H. Jackson, Restructuring the GATT System (Pinter 1990), 52; Jeffrey L. Dunoff, 'Constitutional Conceits: The WTO's 'Constitution' and the Discipline of International Law' (2006) 17 (3) EJIL 647, 652.

${ }^{41}$ See John H. Jackson, 'Sovereignty-Modern and the Constitutional Approach to International Law'(2016) 19(2) JIEL 323.

42 Debra P. Steger, ‘John H. Jackson-WTO Institution Builder' (2016) 19(2) JIEL 339.

43 John H. Jackson, 'Appraising the Launch and Functioning of the WTO' (1996) 39 German Y.B. Int'I L. 20; John H. Jackson, 'Reflections on Constitutional Changes to the Global Trading System' (1996) 72(2) Chi.-Kent L. Rev. 511; John H. Jackson, 'The WTO ‘Constitution' and Proposed Reforms: Seven 'Mantras' Revisited'(2001) 4(1) JIEL 67.
} 
dispute settlement mechanism and have to amend their laws or practices, which also demonstrates that modern international law has made great progress' ${ }^{44}$

\subsection{Human Rights and Basic Freedoms}

At the second stage, IEL scholars were trying to integrate more (social) rights-based values into the regulation of international trade and investment by availing of the institutionalization of IEL. As Churchill said, 'we shape our buildings; thereafter they shape us'. ${ }^{45}$ The constitutional structure of, for instance, the WTO provides us with more room to embrace a rules-based international order at a higher level than ever before. In other words, IEL scholars, nowadays, focus on the extension of international economic governmental organizations' effect. They are no longer satisfied with the rule of law in international trade and investment per se. Rather, they are going to shift the existing rulebook of IEL into a modern version offering all constitutional norms as a whole.

Kumm suggested that global constitutional norms should include certain moral principles as domestic constitutional norms do. ${ }^{46}$ Stephan Schill, another German scholar formed by these ideas, claimed that the universal values of IEL consist of national constitutional principles, the UN Charter, and sustainable development principles and international law. ${ }^{47}$ Petersmann had always claimed in his many writing on this approach that it is necessary to establish a constitutional mind-set within IEL so as to create a citizen-centred conception of international law favourable to rights of citizens and their democratic demand for transnational public goods (PGs). ${ }^{48}$ But also

\footnotetext{
44 Zhipeng He and Lu Sun, A Chinese Theory of International Law (Springer 2020), 219.

45 HC Deb 28 October 1943 vol 393 cc403-73.

46 Mattias Kumm, 'On the History and Theory of Global Constitutionalism' in Thomas Kleinlein and Anne Peters (eds), International Constitutional Law (OUP 2014) 168, 171-2.

47 Stephan W. Schill, 'Reforming Investor-State Dispute Settlement: A (Comparative and International) Constitutional Law Framework' (2017) 20(3) JIEL 649, 652-62.

48 Ernst-Ulrich Petersmann, 'Need for a New Philosophy of International Economic Law and Adjudication' (2014) 17(3) JIEL 639, 639-51; Ernst-Ulrich Petersmann, 'Reforming Multilevel Governance of Transnational Public
} 
other authors in the United States and Germany advocated creating societal constitutionalism so as to bring more social rights in IEL. ${ }^{49}$ Overall, they are trying to use constitutionalism as a method for creating a more inclusive rulebook of IEL, which includes human rights, the rule of law, and democracy, and social values for achieving sustainable development. ${ }^{50}$

\subsection{The Role of European Integration}

Another important element to understand the current use of constitutional ideas and the role of institutions to defend its values is European integration and the mechanisms used to build the European Union (in particular in the original form of the European Economic Community). ${ }^{51}$ Obviously, for some, it is the international institution that comes closer to realizing the ideas of global constitutionalism (in international economic law). It comes as no surprise, that German-speaking scholars therefore often use European integration as the success story for the practical implementation of their ideas. ${ }^{52}$ Here the role of the courts, transparency and administrative and procedures to defend the internal market with its four economic freedoms (free movement of goods, free movement of services, free movement of persons, free movements of capitals) and the use of competition rules to avoid private violations of these freedoms was seen by many as the realization of the constitutionalist dream. At the same time, even here the economic freedoms were rarely called individuals rights (but rather freedoms) and when it came to the external application of these principles (e.g. compliance with WTO

Goods Through Republican Constitutionalism? - Legal Methodology Problems in International Law' (2017) 12(33) AJWH 33, 39; Petersmann, E. U., 'Human Rights, Constitutionalism and the World Trade Organization: Challenges for World Trade Organization Jurisprudence and Civil Society' (2006) 19(3) Leiden Journal of International Law 633, 640 .

49 Anne Peters, 'Global Constitutionalism-The Social Dimension' in Thomas Kleinlein and Anne Peters (eds), International Constitutional Law (OUP 2014); Gavin W. Anderson, 'Societal Constitutionalism, Social Movements, and Constitutionalism from Below' (2013) 20(2) Ind. J. Global Leg. Stud. 881.

${ }^{50}$ Ernst-Ulrich Petersmann, 'Reforming Multilevel Governance of Transnational Public Goods Through Republican Constitutionalism? - Legal Methodology Problems in International Law', supra note 48, 35; Anne Peters, supra note 49; Gavin W. Anderson, supra note 49.

51 See, for a recent overview Danny Nicol, The Constitution Protection of Capitalism (Hart 2010), 82-127.

52 Hence the rebuttal of an European Constitution in 2004/5, the termination of the UK of its EU membership (Brexit 2016-) or the refusal of certain Member States (and their courts) to recognize supremacy of EU law (German Constitutional Court, Hungary, Poland eg.in 2020) come are major challenges for the advocates of European or global constitutionalism. 
rulings) even the EU was less inclined to give up its hegemonic power and to entitle its citizens to exercise the respective economic freedoms by invoking them before the EU courts. ${ }^{53}$ Nevertheless, the current support of the EU of the WTO (and in particular, its dispute settlement system) and their promotion of a multilateral investment court $(\mathrm{MIT})^{54}$ as opposed to more party-driven dispute settlement methods can be seen as expressions of the stronger support for constitutional ideas here than elsewhere. ${ }^{55}$

\section{Criticism}

These ideas of IEL scholars are insightful. Nonetheless, using constitutionalism as a method for extending the existing regulatory effect of international economic governmental organizations in a manner that protects fundamental human rights and pursues sustainable development remains controversial. One can clearly see that those advocating this approach mostly come from a relatively small group of scholars whose education is based on the German experience in the first half of the 20st century. In the US the successors to John Jackson are few these days, probably with the exception of Joel Trachtman who still endorses the constitutional functions of international economic law (and organizations). ${ }^{56}$

\subsection{Hierarchical System vs. Fragmentation?}

Regarding the use of constitutionalism in IEL, there is a heated debate over hierarchy and fragmentation. ${ }^{57}$ The question here is whether the constitutionalization of a single branch of international law, IEL for instance, can be regarded as a real

\footnotetext{
${ }^{53}$ Much to the regret of constitutionalists, see Ernst-Ulrich Petersmann, 'Will the EU degenerate into a Banana Republic' (1995) 32 CMLRev.1164.

54 Marc Bungenberg and August Reinisch, From bilateral arbitral tribunals and investment courts to a multilateral investment court (Springer 2018).

55 See Thomas Zimmermann, Negotiating the Review of the WTO Dispute Settlement Understanding (Cameron May 2006) 224.

56 See e.g., Joel Trachtman, The International Economic Law Revolution and the Right to Regulate (Cameron May 2006), $27 \mathrm{ff}$.

57 For a good overview on this debate see Peter-Tobias Stoll, 'Constitutional Perspectives on International Economic Law', in Marise Cremona, Peter Hilpold, Nikos Lavranos, Stefan Staiger Schneider and Andreas R. Ziegler, Reflection on the Constitutionalization of International Economic Law (Nijhoff 2014).
} 
constitutionalization of international law (and politics) or of the global order or of the international community as constitutionalist would say.

For some scholars, like Zhipeng $\mathrm{He}$ for instance, the lack of a unified institutionalization of international law is critical and thus the use of constitutionalism in the context of international law is impossible due to structural obstacles. ${ }^{58}$ Zhipeng He criticized that:

'These seemingly global institutions actually all have institutional defects. The cooperation between various specialized agencies of the United Nations seems to have formed a relatively mature system of coordination and division of labor, but this is only superficial and elementary, and far from forming an organic system. The WTO which is most influential in the field of economic and trade is not a specialized agency of the United Nations, and there is no structural connection between the organizations in the monetary and financial sectors and trade organizations... Thus, the fact that we must face is that, not only are the norms of international law fragmented and separate, and the implementation of international law is only aimed at nations or international organizations and related actors that recognize these rules, but also between international law enforcement agencies and international judicial agencies there is no division of labor and coordination, and they are respectively independent and acting as they think proper. ${ }^{, 59}$

Nevertheless, other scholars were of the view that the hierarchy is not necessary in the context of global constitutionalism. In his book entitled 'The Cosmopolitan

\footnotetext{
58 Zhipeng He and Lu Sun, supra note 44, 238-40.

${ }^{59}$ Ibid, 212.
} 
Constitution', Somek defended a managerial anarchy. ${ }^{60}$ To his mind, a permanent centralized authority appears to be quite unnecessary because the anarchical quality of transnational governance does not imply that it is chaotic. ${ }^{61}$ He even takes the WTO as a multilevel regulatory pattern: the WTO and other regulatory authority, either national or regional, use the same international standard set by the Codex Alimentarius Commission to resolve issues regarding permissible food ingredients. ${ }^{62}$ Moreover, according to Neil Walker's theory of constitutional pluralism, the rulebook of a collective body beyond the nation state can be called as a constitution so long as it meets several conditions. ${ }^{63}$ The institutional hierarchy is of course not included in these conditions. Likewise, Gunther Teubner was of the view that there is no unitary global constitution overlying all areas of society but rather the constitutionalization of a multiplicity of autonomous subsystems of world society. ${ }^{64}$ In the light of his theory, IEL should be regarded as an auto-constitutional regime creating highly specialized primary rules and producing its own procedural norms on law-making, law recognition, and legal sanctions. ${ }^{65}$

\subsection{Economic Freedoms v. Human Rights?}

In addition, there comes criticism from within the constitutionalist movement (or more particularly those advocating a strong protection of human rights through international law) against the use of constitutional ideas for economic activities. ${ }^{66}$ In a nutshell, this is another facet of an old debate as to whether the right to property, the right to engage into economic activities have the same value as other human rights, in particular to what is often referred to as economic, social and cultural rights. ${ }^{67}$ While writers like

\footnotetext{
60 Alexander Somek, The Cosmopolitan Constitution (OUP 2014), 228-32.

${ }^{61}$ Ibid, at 230 .

62 Ibid, at 231.

${ }^{63}$ Neil Walker, 'The EU and the WTO: Constitutionalism in a New Key' in G. de Burca and J. Scott (eds), The EU and the WTO: Legal and Constitutional Issues (Hart 2001), 33.

${ }^{64}$ Gunther Teubner, 'Fragmented Foundations: Societal Constitutionalism beyond the Nation State' in Petra Dobner and Martin Loughlin (eds), The Twilight of Constitutionalism? (OUP 2010), 329.

65 Ibid, 333.

${ }^{66}$ For a business-friendly analysis see CATO Institute, The Right to Property in Global Human Rights Law (Policy Report, 2011).

67 See for example, Danny Nicol, supra note 51, 47-81.
} 
Petersmann, Hilf and Cottier ${ }^{68}$ advocate the protection of individual rights to trade and invest as important human rights (subject to the same limitations and balancing as other human rights) traditional human rights lawyers often object to this view. ${ }^{69}$ As a consequence, they also fear that the rule of law, direct effect, enforcement by courts ${ }^{70}$ and transparency in this field could be detrimental to the achievement of the traditional human rights (in particular of workers, indigenous people other vulnerable groups). ${ }^{71}$

In a nutshell, certain writers and group object to the idea that the rights of traders and Investors (which they normally identify as mostly multinational companies) should be treated equally as the economic(and social rights) of workers and "normal people". As long as millions suffer from famine, poverty, environmental pollution, etc. they warn against the absence of hierarchy between economic freedoms (trade, investment, intellectual property rights) and (Basic) human rights (right to work, right to water, right to food, right to a healthy environment etc.). ${ }^{72}$

\subsection{Economic Constitutionalism and Economic Theory: Which type of Liberalism ?}

\footnotetext{
${ }^{68}$ See for example, Thomas Cottier, 'The Constitutionalism of International Economic Law' in Karl M. Meessen, Marc Bungenberg, and Adelheid Puttler, Economic Law as an Economic Good, Its Rule Function and its Tool Function in the Competition of Systems (Sellier European Law Publishers 2009), 317-33.

69 See Meinhard Hilf, 'Die WTO - Eine Gefahr für die Verwirklichung von Menschenrechten?'(2005) 43(4) Archiv des Völkerrechts 397. See also Andreas R. Ziegler and Bertram Boie, 'The Relationship between International Trade Law and International Human Rights Law' in Erika de Wet and Yure Vidmar (eds), Hierarchy in International Law - The Place of Human Rights (OUP 2012).

70 See for example Meinhard Hilf, 'The role of national courts in international trade relations'(1997) 18(2), Michigan Journal of International Law 559.

71 See the famous debate between Ernst-Ulrich Petersmann and Philippe Alston in the European Journal of International Law: E.-U. Petersmann, 'Time for a United Nations 'Global Compact' for Integrating Human Rights into the Law of Worldwide Organizations: Lessons from European Integration' (2002) 13(3) EJIL 621; R. Howse, 'Human Rights in the WTO: Whose Rights, What Humanity? Comment on Petersmann' (2002) 13(3) EJIL 651; P. Alston, 'Resisting the Merger and Acquisition of Human Rights by Trade Law: A Reply to Petersmann' (2002) 13(4) EJIL 815; E.-U. Petersmann, 'Taking Human Dignity, Poverty and Empowerment of Individuals More Seriously: Rejoinder to Alston' (2002) 13(4) EJIL 845; and a second time E.-U. Petersmann, 'Human Rights, International Economic Law and Constitutional Justice'(2008) 19(4) EJIL 769; P. Carozza, 'Human Dignity and Judicial Interpretation of Human Rights: A Reply' (2008) 19(5) EJIL 931; R. Howse, 'Human Rights, International Economic Law and Constitutional Justice: A Reply' (2008) 19(5) EJIL 945; E.-U. Petersmann, 'Human Rights, International Economic Law and Constitutional Justice: A Rejoinder' (2008) 19(5) EJIL 955. See also International Law Association, Resolution 5/2008 on Human Rights and International Trade Law (ILA Report 2008).

${ }^{72}$ See e.g. P. Alston, 'Resisting the Merger and Acquisition of Human Rights by Trade Law: A Reply to Petersmann', supra note 71, 815-44 and below Point 4.
} 
A particular subcategory of this latter form of criticism stems from the economic theories used by those who identify as constitutionalist to analyse the economic foundations of (constitutional) norms of international economic law. Writers like Petersmann often refer to economist like Wilhelm Röpke (1899-1966), Ludwig von Mises (1881-1973), Michael A. Heilperin (1909-1971), Friedrich August von Hayek (1899-1992), Lionel Robbins (1898-1984), Gottfried Haberler (1900-1995), and Jan Tumlir (1926-1985). These are described by the critics of these writings as neo-liberals, ordo-liberals or simply the Geneva School of Neoliberalism. ${ }^{73}$ The core features at stake here are again the role of Government in society and to what extent specific rights of people undertaking economic activity (investment, trade, intellectual property) should be protected from state intervention. The debate very much relates to the degree of market intervention, going from total absence (laissez-faire or Manchester liberalism) to total State control.

Most of the writers we identified as defendants of constitutional ideas in IEL advocate that some degree of state intervention is justified but that it should be follow the general rules with regard to all limitations of human rights (like transparency, predictability etc.), in particular that it should be rule-based, serve a legitimate public interest (this can such economic (public) goods like competition), non-discriminatory and possible proportionate. They underline that the ordoliberalists "were more attentive to questions of international economic order as a condition for empowering welfare states and limiting abuses of public and private powers" than those who are usually identified as Manchester Liberals (of the $19^{\text {th }}$ century like John Bright und Richard Cobden) or neoliberalists of the $20^{\text {th }}$ century (like Milton Friedman [1912-2006] and the Second Chicago School).

At the centre of the debate is often the question to what extent liberal ideas of the $20^{\text {th }}$ century (often simplified as neo-liberalism) allows for a sufficient defence of specific

\footnotetext{
73 Most recently.
} 
public goods and human rights (at the domestic level often equates with the welfare State) while at the same time limiting State intervention. Those usually referred to as ordo-liberals (Walter Eucken, Franz Böhm) or even social ordo-liberalists (Alexander Rüstows, Wilhelm Röpke) tried to integrate social cohesion and the safeguard of ethical principles but this was not always recognized as successful or sufficient. They were reacting to three shocks: World War I, the Great Depression, and decolonization. One could probably add the opposition to communism (and even socialism), that for example very much dominates the work of Friedrich A. Hayek. ${ }^{74}$

As a remedy they proposed that international institutions should provide a regime that guaranteed property rights and international division of labour based on stability. ${ }^{75}$ The critics see them as neglecting economic, social and cultural rights of vulnerable groups and the poor. Some of them argue that these neoliberal ideas defend property and economic rights of investors and multinational companies just to protect the status quo. $^{76}$ This again is seen as an unfair assessment: "The interwar fathers of modern neoliberalism were responding to a 1930s world of arbitrary confiscation of propertyoften based on national, racial, or religious identity - that was an intrinsic part of marginalization, dehumanization, and ultimately destruction. Their analysis cannot be used to object to taxation, even high and progressive taxation, as long as it is equally and impartially applied. The defence of property was a part of, and emanated from, deeper concern with the protection of human dignity. ${ }^{77}$ Economic rights (in the sense of property rights) are thus no absolute rights but they can be limited according to the principles described (rules of law, public interest, non-discrimination and possible proportionality). At the same time, they deserve protection.

\footnotetext{
${ }^{74}$ See for example, Friedrich A. Hayek, The Road to Serfdom (first published 1944, University of Chicago Press 2007) and much later Friedrich A. Hayek, The Fatal Conceit: The Errors of Socialism (University of Chicago Press 1988).

75 See also Harold James, 'From Vienna to the WTO: Book Review,-Globalists: The End of Empire and the Birth of Neoliberalism. By Quinn' (2018) 55(3) Finance \& Development 59.

76 See the most recent debate between Quinn Slobodian, Globalists: The End of Empire and the Birth of Neoliberalism (Harvard University Press 2018) versus Ernst-Ulrich Petersmann, 'Book Review,- Globalists: The End of Empire and the Birth of Neoliberalism. By Quinn Slobodian'(2018) 21(4) JIEL 915.

77 See Harold James, supra note 75.
} 


\section{The Political Relevance of Constitutionalism in the Context of IEL}

Many scholars have written on the use, abuse and usefulness of (global) constitutionalism as a method in IEL. ${ }^{78}$ The politically most compelling question remains whether the use of constitutionalism is feasible at the international level or is too ideal (as opposed to the more traditional realist theories that foresee almost unlimited sovereignty for nation States). ${ }^{79}$

That question can be shifted into two sub-questions: (1) The question of how to reach a consensus on the content of international constitutional norms; and (2) the question of whether these international constitutional norms can be implemented at the national level in a state-centred world order. ${ }^{80}$

\subsection{Reaching Consensus on the Content of IEL}

\footnotetext{
78 Deborah Z. Cass, The Constitutionalization of the World Trade Organization Legitimacy, Democracy, and Community in the International Trading System (OUP 2005); Jeffrey L. Dunoff, supra note 40; Samantha Besson, 'Whose Constitution(s)? International Law, Constitutionalism, and Democracy' in Jeffrey L. Dunoff and Joel P. Trachtman (eds), Ruling the World? Constitutionalism, International Law, and Global Governance (CUP 2009); Richard Collins, 'Constitutionalism as Liberal-Juridical Consciousness: Echoes from International Law's Past' (2009) 22(2) Leiden Journal of International Law 251; Christine E. J. Schwöbel, 'Situating the debate on global constitutionalism' (2010) 8(3) I·CON 611; Christine E. J. Schwöbel, ‘Organic Global Constitutionalism' (2010) 23(3) Leiden Journal of International Law 529; Johannes Gerald Van Mulligen, 'Global Constitutionalism and the Objective Purport of the International Legal Order' (2011) 24(2) Leiden Journal of International Law 277; Michel Rosenfeld, 'Is Global Constitutionalism Meaningful or Desirable?' (2014) 25(1) EJIL 177; David Schneiderman, 'Against Constitutional Excess: Tocquevillian Reflections on International Investment Law' (2018) 85(2) U. Chi. L. Rev. 585; Dimitri Vanoverbeke, 'Are We Talking the Same Language? The Sociohistorical Context of Global Constitutionalism in East Asia as Seen from Japan's Experiences' in Takao Suami, Anne Peters, Dimitri Vanoverbeke, and Mattias Kumm (eds), Global Constitutionalism from European and East Asian Perspectives (CUP 2018); Matthieu Burnay, 'Chinese Perspectives on the Rule of Law' in Takao Suami, Anne Peters, Dimitri Vanoverbeke, and Mattias Kumm (eds.), Global Constitutionalism from European and East Asian Perspectives (CUP 2018); Mark Tushnet, 'The globalisation of constitutional law as a weakly neo-liberal project' (2019) 8(1) Global Constitutionalism 29; Gila Stopler, 'Semi-liberal constitutionalism' (2019) 8(1) Global Constitutionalism 94.

79 See, most recently, Andraž Zidar, The World Community between Hegemony and Constitutionalism (Eleven 2019). It should be noted that this debate applies also to constitutional thinking in many domestic systems. See, for example, for the United States Jeremy Waldron, 'Constitutionalism - A Skeptical View' in Thomas Christiano and John Christman (eds), Contemporary Debates in Political Philosophy (Blackwell 2009) or Murray N. Rothbard, For a New Liberty: The Libertarian Manifesto (first published 1973, Collier Books 1978), 48.

80 See, for example, Jeffrey L. Dunoff, supra note 40, 647-75.
} 
Reaching a consensus on the content of international constitutional norms is nearly impossible against the current backdrop of international politics. The deadlock of WTO negotiations (approximately since 1995) is the epitome of that difficulty. It seems that a citizen-centred international community is necessary for modernizing the existing IEL in a manner that ensures international constitutional norms. Nonetheless, such a citizencentred international community described, for instance, in the preamble to the UN Charter has not been realised yet. Furthermore, such consensus can also diminish over time, e.g. the Brexit with regard to the purpose and objectives of the European Union.

The history of constitutionalization in Japan can also provide (a less well known) insight into the consensus-building of international constitutional norms. The Japanese experience unveiled the relationship between autocratic rulers and their people and between democracies and non-democratic countries in the process of constitutionalization. It showed two significant points: (1) Japanese rulers and their people shared no common attitude towards the implication of constitution; (2) the intervention of the U.S., a powerful democracy, played a role in drafting a thick constitution in the Empire of Japan, a non-democratic country. ${ }^{81}$ Citizens are at the first degree of constituent power to formulate a constitution. However, the bottom-up process of constitutionalization prevailing in democracies is wholly reversed in nondemocratic countries, and thus the first degree of constituent power is not belonging to citizens, as shown in the process of promulgating the Meiji Constitution in the Empire of Japan. ${ }^{82}$ In the same vein, constitutionalism is hard to be realised at the international level. In the extant international community, both democracies and non-democratic countries participate in the drafting of international law. If members of the international community decide to set up a series of international constitutional norms, therefore, both democracies and non-democratic countries, holding different stance on the implication of constitution, are constituent members. Against this background, it is difficult to reach a consensus on international constitutional norms. It is therefore hard

\footnotetext{
81 Mattias Kumm, supra note 46, 209-11.
}

82 Ibid. 
to use constitutionalism as a method for achieving the objective of creating an inclusive rulebook of IEL including the whole family of constitutional norms. As Jean d'Aspremont notes, the huge obstacle to the cooperation between democracies and nondemocracies is self-evident, even though the door of searching for a diplomatic solution is ever open. ${ }^{83}$

\subsection{Implementation of IEL at Domestic Level}

As stated above, implementing international constitutional norms at the national level is also difficult. As Kun notes, addressing a global legal issue always hinges on solutions at the local level. ${ }^{84}$ Those solutions at the national level are key to implement an international consensus, notably when it has to be implemented by States that do not share a common legal tradition or political stance. Nonetheless, in the majority of cases, there is no common solution at the national level. As Besson notes, there is no shared understanding for many terminologies used in the practice of international law serving as a consensus of the international community. ${ }^{85}$ As a result, there is a dilemma. Even if the international constitutional norms were accepted universally by the members of the international community, those norms cannot be implemented in each State due to different interpretations (e.g. universal meaning of specific human rights).

An additional debate relates normally to the protection of agreed international rules (especially treaty provision) at the domestic level. To what extent should they benefit from supremacy with regard to (domestic laws)? Should domestic courts be entitled to rule on individual claims based on these international treaties? We are thus confronted with the typical problems in relation to the role of international law at the domestic level which are particularly controversial when it comes to individual human rights

\footnotetext{
${ }^{83}$ See also Jean d'Aspremont, L'état non démocratique en droit international Étude critique du droit international positif et de la pratique contemporaine (Editions A. Pedone 2008).

${ }^{84}$ For example, Kun Fan, 'Glocalization' of International Arbitration-Rethinking Tradition: Modernity and EastWest Binaries Through Examples of China and Japan (2016) 11(2) University of Pennsylvania East Asia Law Review 244.

85 Samantha Besson supra note 78, 394.
} 
(including those of investors, consumers or traders). The creation of international courts can be a remedy (that remains rare and vulnerable) - the current discussions on the future of the international (regional) human right courts, but also investor-state dispute settlement (ISDS) and the WTO dispute settlement understanding are perfect examples of this aspect of constitutionalism.

Failure to address those two problems (which common norms and how to protect them) results in an impasse: constitutionalism cannot be used for creating and defending global public goods (a healthy environment, sustainability, peace etc.) and integrating fundamental (human) rights including social rights (respect for human dignity, absence of violence, absence of poverty, equality, access to food, etc.) into the regulation of international trade and investment. ${ }^{86}$ Against this background, the acceptance of constitutionalism serving as a methodology for shifting IEL into a social rights-based rulebook that recognises international constitutional norms is doubtful. As a result, more and more scholars prefer to achieve that objective by using an alternative method.

Cass and Schwöbel emphasized the impact of politics on the use of constitutionalism as a method in IEL. They intended to evade political interventions. Cass shifted the constitutionalization of the WTO into a legal process. To her mind, the WTO Appellate Body can generate so-called constitutional norms. She named her approach as a judicial norm-generation approach compatible with standard U.S. constitutional law theory. ${ }^{87}$ In the view of Cass, that approach allows the WTO to adopt constitutional norms without explicit normative claim in its decision-making process, ${ }^{88}$ and realign traditional sovereign relations among constituent entities and between itself and those sub-parts through a such deliberative process. ${ }^{89}$ Schwöbel advocated shifting the

\footnotetext{
86 See the many writing in the last 30 years on "Trade and..." as well as more recently "Investmen and..." (focusing on the environment, human rights, culture, gender equality etc., e.g., Andreas R. Ziegler, "WTO Rules Supporting Environmental Protection' in Friedl Weiss et al (eds), International Economic Law with a Human Face (Brill 1998).

${ }^{87}$ Deborah Z. Cass, supra note 78, 177-8.

88 Ibid., 22.

${ }^{89}$ Ibid., 19 .
} 
constitutionalization of the WTO into an ongoing process without pre-political common values. He placed the discursive political determination at the heart of his solution. ${ }^{90}$ Patel emphasized the role of political economy in reaching a consensus on international constitutional norms between States. ${ }^{91}$

Moreover, the insightful consideration of Schneiderman was also representative. Like many scholars, Schneiderman contended that the use of constitutionalism as a method in IEL is excessive. He opined that international investment law per se should constitute the constitution of international investment. However, he considered that the ideal balanced constitution defined by Tocqueville is unrealistic at the international level, ${ }^{92}$ and thus the use of constitutionalism as a method in international investment law should remain at the already-existing level. ${ }^{93}$

\section{The Prospect of Constitutionalism in IEL}

It seems that there is no prospect of using constitutionalism as a method for integrating constitutional norms into IEL against the current backdrop of international politics. Indeed, there are so many depressing facts suggesting that we cannot realise that objective by availing of constitutionalism. De-constitutionalization and the crisis of multilateralism risk undermining the existing international order based on the UN Charter and universal norms thereof. The Trump administration's international affairs policies increased the difficulty for the international community to reach a consensus on international constitutional norms. ${ }^{94}$ And the current challenges to European integration and so many other geopolitical tensions generated unstable factors to the maintenance of a rule-oriented international order as well.

\footnotetext{
${ }^{90}$ Christine E. J. Schwöbel, supra note 78, 539.

91 Christine Schwöbel-Patel, supra note 5, 104.

92 David Schneiderman, supra note 78.

93 Ibid.

94 During the Trump administration, the U.S. has withdrawn from the Paris Agreement, Intermediate-Range Nuclear Forces Treaty, and one of the most important components of the UN, the United Nations Human Rights Council.
} 
Nonetheless, it stands to reason that constitutionalism still plays a role in IEL. It is a method necessary for guiding global politics (and hopefully some form of shared governance) led by all States (potentially through the UN and specialized global international organizations like the WTO). Although alternative solutions are insightful in filling the vacuum that low-level global constitutionalism left in the existing international rule of law, they cannot supplant the function of constitutionalism at the normative level. After all, constitutional norms have been standing for the cornerstone of the international rule of law. This is the reason why no State denies that those norms are part of international law centred on the UN Charter, though the international community is facing off a big split.

If international economic governmental organisations keep on following the spirit of the UN Charter, therefore, constitutionalism should still be regarded as a method essential for IEL. As a matter of fact, constitutionalism has been playing a role in guiding the development of IEL in a manner that supports good global governance, though IEL scholars often emphasized that point from different perspectives in each period. As Peters notes, international constitutionalism (at least) stimulates the search for new mechanisms to strengthen the legitimacy of global governance. ${ }^{95}$ The motivation for IEL scholars to use constitutionalism as a method in IEL can be shifted into that to reshape the regulatory framework of international trade and investment in a manner that meets the requirements of good global governance. That follow-up of good global governance in IEL can be found at both the institutional level and normative level.

On the one hand, the institutionalization of IEL responds to the need to establish a rulebased international order. The WTO's constitutional structure and establishment of international investment tribunals are good examples. Thanks to those institutional arrangements, the political intervention on the regulation of international trade and

\footnotetext{
95 Anne Peters, 'Compensatory Constitutionalism: The Function and Potential of Fundamental International Norms and Structures' (2006) 19(3) Leiden Journal of International Law 579.
} 
investment has been limited to some degree. We take the current trade tensions as an example. Although each State can unilaterally take measures to attempt to realise its particular economic or political objectives outside the WTO system, its action, such as tax measure, cannot jump out of the jurisdiction of the WTO dispute settlement body, and thus that WTO-inconsistent measure will be rejected. Once a State's unilateral action is judged as illegal, other countries have the right to retaliate it. In many cases, the decision of the WTO judiciary has made States fail to achieve their illegal objectives. Although people can imagine that a superpower withdraws from the WTO so as to get rid of that institutional constraints, no State even attempted to do so ever to date. In this sense, the WTO's regulatory function is incomparable in the realm of international trade and investment, though its reach is not ideal.

On the other hand, the attempt to reform the rulebook of IEL also meets the requirements of good global governance. Good global governance is meant to ensure the administration of human collectivities in the name of a higher moral principle that sees the preservation of life and the alleviation of suffering as the highest value of action. ${ }^{96}$ As Barnett notes, global (humanitarian) governance needs the intervention of global institutions for advancing the values creating the best world in the lives of others. ${ }^{97}$ In other words, to achieve global (humanitarian) governance, international economic governmental organizations have to not only serve as a regulator of international trade and investment but also applies these norms necessary for global (humanitarian) governance.

In the light of the preamble to the UN Charter, good global governance is supposed to ensure a series of norms including fundamental human rights, the dignity and worth of the human person, the equal rights of men and women and of nations large and small, and justice and respect for the obligations arising from treaties and other sources of

\footnotetext{
96 Didier Fassin, supra note 29, 151.

${ }^{97}$ Michael Barnett, 'Paternalism and Global Governance' (2015) 32(1) Social Philosophy and Policy 216.
} 
international law, and social progress and better standards of life in larger freedom. ${ }^{98}$ We recall that constitutionalism generally means a limitation of power, the institutionalization of power, social idealism, the standard-setting capacity of constitutions in the sense of a systematization of law, and the recognition of individual rights. ${ }^{99}$ By comparing the contents of the UN Charter and those implications of constitutionalism, we can find a matching. In view of this, IEL scholars can in principle use constitutionalism as a method for integrating those values of good global governance into the rulebook of IEL.

Although the future is unpredictable, constitutionalism will no doubt play a role in reforming IEL in a manner that supports good global governance. Of course, it is difficult for IEL scholars to realise their objectives by availing of constitutionalism in the short term. That success has to wait for a juncture as what has happened in history. However, constitutionalism is no doubt a meaningful method in IEL, given it is still the ideal way towards bringing these norms necessary for good global governance into the rulebook of IEL.

\section{Conclusion}

This chapter emphasizes two points with respect to constitutionalism as a method in IEL: First of all, constitutionalism is an important method in IEL given it has significantly contributed to the regulation of international trade and investment in the last 75 years. Its contribution to the institutionalization of IEL and the compliance with its rules remain necessary for promoting the prosperity of international trade and investment and thereby contributing to increased welfare of humanity as a whole when the basic principles of sustainable development are respected.

\footnotetext{
98 The UN Charter, Preamble.

99 Christine Schwöbel-Patel, supra note 5, 104.
} 
Secondly, despite the current problems as to the implementation of constitutional ideas in IEL, constitutionalism as a method for developing IEL remains attractive. On the one hand, the current debates per se can be seen as the result of a huge development of IEL inspired by constitutionalism (judicialization, transparency, precise foreseeable rules, dispute settlement etc.). On the other hand, constitutionalism will be an indispensable method for reforming IEL in a manner that supports the UN's good global governance in the long term. From a functional approach, the methods and objectives of constitutionalism allow for undertaking a series of missions aiming at good global governance. Those missions include the realisation of the UN's sustainable development goals (2015), such as the fight against climate change. Given those missions lie at the heart of the good global governance, and that international economic governmental organizations are important actors of those missions, constitutionalism will still be needed as a method - also in IEL.

Therefore, constitutionalism as a method in IEL is neither omnipotent nor useless. It may be that as of today for many governments the terms "constitutionalism" or "constitutionalization" remain taboo when it comes to global politics and decision making while they are willing to accept (at least) certain of its elements without calling them constitutional in nature. After all, political tensions (and academic controversies) always lead to new situations which results in both challenges and opportunities. Once the current backdrop against multilateralism in general and the WTO in particular becomes less strong, the role of constitutionalism as a method for developing IEL may be more important and fruitful. 